\title{
Political-Administrative Dichotomy: Its Sources, Logic and Debates
}

\author{
Shengyun Guo \\ School of Public Administration, Jinan University, Guangzhou, China \\ Email: gdnxgsy@163.com
}

How to cite this paper: Guo, S.Y. (2019) Political-Administrative Dichotomy: Its Sources, Logic and Debates. Open Journal of Social Sciences, 7, 356-368. https://doi.org/10.4236/jss.2019.73030

Received: February 28, 2019

Accepted: March 19, 2019

Published: March 22, 2019

Copyright $\odot 2019$ by author(s) and Scientific Research Publishing Inc. This work is licensed under the Creative Commons Attribution International License (CC BY 4.0).

http://creativecommons.org/licenses/by/4.0/

\begin{abstract}
Since its birth in Europe in the $19^{\text {th }}$ century, the theory of political-administrative dichotomy has come into maturity via the help of Wilson and Goodnow. As the theoretical cornerstone of Public Administration, political-administrative dichotomy has a profound historical root, and yet still provoked vehement arguments and confrontations. This article tries to present a line of argument about the identity of public administration at large, as well as that embedded in Chinese context, by articulating both the historical background and theoretical course, and the famous criticism of public administration by Waldo. Our conclusion is that in China's context, we can never properly understand governance environment and logic in China if we over-estimate the separation and distinction of politics and administration.
\end{abstract}

\section{Keywords}

Political-Administrative Dichotomy, Logic, Chinese Context, Governance

\section{Introduction}

Since the beginning of public administration, the relationship between politics and administration is a core issue in this field [1]. It is closely related to the identity of public administration, and it also strongly influences the practice of public administration and constitutes an important cornerstone of public administration. The political and administrative dichotomy is one of the most important and most discussed concepts on this topic. Since Wilson first stated it, it also experienced the peaks and valleys of development. Although it provided the premise for the development of public administration, it was widely criticized by the academic community. Even so, how to define the relationship between politics and administration is still of great significance to the development of public administration in theory and practice. Therefore, people constantly reflect and 
criticize the political-administrative dichotomy, which objectively promotes the theory of public administration in theory and practical development. This article will sort out the historical background and theoretical course of the political-administrative dichotomy, and discuss the criticism of Waldo and the reality of China's public administration.

From the beginning, we need to understand its definition. Wilson, who is known as the originator of administrative science, clearly pointed out that politics and administration are two different fields of study. He agrees with Bluntschli's view that administration is not within the scope of politics. The issue of administrative management is not a political issue. Although the task of administrative management is determined by politics, politics does not have to ask for trouble to directly direct the administrative agency. "Politics is a major and universal matter." In terms of national activities, administration is the activity of the state in individual and subtle matters. "Politics is the special activity of politicians and administrative management is the matter of technical staff." It is based on this understanding that Wilson distinguishes politics from politics. Later, People put it into the principle of political-administrative dichotomy.

\section{Historical Background of the Political Administration}

To understand any theory, we must first examine the historical background on which it is produced and developed. It is no exception to the political and administrative divide. It is generally believed that the presenter of politics and administration dichotomy is the father of American public administration Wilson, so we will first focus on the development of American public administration.

\subsection{Limited Government: American Liberal Tradition}

Liberalism is one of the political ideologies in which Western society dominates, but it is difficult to describe its true appearance under the veil. "It is more like a family portrait made up of various principles and institutions, and can be distinguished by characteristics such as individual freedom, political participation, private property and equal opportunity" [2]. Modern Western institutions are mostly based on liberal principles and values. The United States does not have feudal oppression and religious oppression compared to European political history. Therefore, Louis Hartz said that the United States is a liberal society from beginning to end. Liberalism is the only political and ideological tradition in the United States that dominates. Early American Puritan immigrants were a group of rebels of the old system, and their religious reforms inadvertently offered the possibility of liberalism. More than a century in the British colonial era was a period of British liberalism's development and perfection. It coincided with the history of the United States, and the genes of freedom and equality began to exist from generation to generation. In this regard, Tocqueville also said: "The biggest bargain for Americans is that they did not establish a democratic system through a democratic revolution; and they were born to be equal, not later equal." 
Freedom and equality have led the American people to try to restrict public power and protect individual rights when establishing political power. The federal constitution, which was a triumph of the class struggle, profoundly reflects this feature. In the introduction, it succinctly explains the purpose of constitutionalism. "We, the people of the United States, build a better federation, establish justice, guarantee domestic peace, provide common defense, promote public welfare, and free ourselves and future generations. The happiness of this constitution is specially formulated for the United States of America." This short sentence fully embodies the importance of the value of freedom in American public life. Thus, in the creation of this government system for the purpose of guaranteeing "freedom of liberty", the constitutionalists institutionalized the understanding of political freedom and civil liberties, and established a government with separate powers and checks and balances system. Under this system, which strongly restricts government power, the government plays the role of "negative government" in conformity with the requirements of the bourgeoisie. Its functions are limited to protecting free competition, safeguarding private property, and establishing certain necessary public utilities and public facilities. But another problem emerges, that is, public administration is less concerned as a special issue. Compared with European countries, the system and practice of American public administration is relatively slow, and it is impossible to form a theory. French scholar Alexis de Tocqueville traveled in the United States when the US public administration activities freely also surprised, "Public administration in the United States is almost entirely based on oral and traditional. There is no written rule, no one studies management methods, no one sums up experience, collecting documents is very easy, but no one collects. Documents that accidentally fall into people's hands are rarely kept, administrative staff simply does not learn from each other, and they only rely on their own accumulated experience and knowledge when guiding social work, but they do not have the scientific knowledge necessary to guide the work". The development of theory comes from the needs of reality, and the US government "has only enjoyed a public nature of authorization for a long time" [3]. Correspondingly, Public administration was also in an unattended state during this period. But the arrival of the industrial revolution has quietly changed all of this.

\subsection{Active Government: Reflection from the Industrial Revolution}

Within 36 years after the end of the Civil War, the United States has experienced rapid and successful industrial revolution, to achieve the transition from liberal capitalism to monopoly capitalism, the great changes in US history, socio-economic and political life took place. In a relatively short period of time, the United States transition from an agricultural country to industrial countries, will inevitably lead to urbanization and industrialization, making the United States a high concentration of urban population and attract a large number of immigrants. At the same time, the free market has developed at an unprecedented rate, economic competition has intensified, industrial and financial industries have become 
more concentrated, and monopolistic companies have played a pivotal role in the US economy. The scientific and technological advances brought about by the industrial revolution have unleashed enormous energy that is unimaginable, and have had a wide and profound impact on all areas of American society. The concept of progressivism is therefore deeply rooted in the hearts of the people.

"Industrialization, urbanization, and the influx of immigrants" have changed the old look of American society, but any development requires a price, and it also brings many economic, social and political issues. The market economy that has been unprecedentedly developed under the government's laissez-faire policy has gathered huge amounts of wealth and brought about a serious polarization. On the one hand, individual chaebols have mastered the lifeline of the national economy, while on the other hand, countless poor people are struggling in the harsh living environment. At the same time, the balance between politics and the economy that the government has maintained with "doing nothing" has been broken. The state power system represented by government organizations is declining, and the economic power represented by large enterprises is constantly increasing. The monopoly economic group behind large enterprises not only realized the control of economic resources, but also bought government officials to obtain political support. The corruption phenomenon is rampant in all levels of US government, and American society is facing a serious crisis. How to prevent monopoly, ease the disparity between the rich and the poor, maintain social stability, and protect freedom and democracy have become tasks that the United States should not delay at the moment. However, the state governance structure established in the early days of the founding of the United States with limited government and party politics as the core can not only help solve various complex social problems, but also become part of the problem. Americans who were once obsessed with liberalism could not help but question it. They are beginning to realize the necessity of government as a positive and limit outsized expectations of private economic power entrusted to government as the representative of public authority. To achieve a transition from "negative" to "positive", he government needs to undergo a series of institutional changes and practical innovations, as well as the demand for specialized administrative personnel and administrative management scientific knowledge. Eventually, people to change the status quo on the needs and expectations into a vigorous progressive movement in the late 19th century.

\subsection{Political-Administrative Dichotomy: A Strategic Tool for Political Reform}

Late 19th century to the 1920s in the United States set off a wave of reform shares, historians called Progressive Movement. In the political arena, the ill-conceived parties are divided into targets for the reformers to focus on. The United States has a strong democratic political tradition, and one of its most important features is that government officials are generally elected. As Sambard said: "To say that it (the United States) has a truly democratic government sys- 
tem means that universal suffrage has now become the rules of the federal states". In the initial period, the number of voters and elected officials was still small, and the principle of democratic elections was later applied to all officials, a situation that continued until the mid-19th century. During this period, in order to meet the needs of the election, professional politicians and professional political organization came into being, known as the "political machine" of party politics on the historical stage. In American party politics, political parties and official positions are closely linked. In 1829, President Andrew Jackson push through the "spoils system" has been institutionalized in the United States and generally popular. Its basic principle is that "the winner is divided into fat", that is, the political party that wins the election can give the government public office as a reward for its active supporters. This means that the appointment of officials is not based on ability, but on the degree of loyalty to the party based on the position of the position. At that time, this system ended the situation of high-level monopoly government management with the superficial official rotation system, which seems to be more consistent with the US democracy and equal value. However, "fertilization" has made a large number of incompetent political officials occupy high positions, and various corruption phenomena such as collusion between officials and businessmen and power for personal gains are not uncommon. Civil service reform in the 1870s was to counter the then chaotic political system [4]. At that time, the biggest drawback of the traditional government management system was that politics and administration were not divided, which was easy to breed corruption and led to inefficiency. To this end, the civil service reformers argue that the government had to a lot of the work is non-political, and asked to establish a dedicated civil service ranks by merit system. You can see, the Progressive Era political reform is built on top of each other for political and administrative independence to understand, trying to make it professional administrative staff to handle specialized government affairs, so that elected political officials, according to the people vote determine the distribution of social values. This is the initial framework of political and administrative dichotomy. Its purpose is to separate administrative management from party politics and make administration a non-political tool.

Overall, politics and administration dichotomy of the concept of development occurs in a series of American narrative. The establishment of the American political system is deeply influenced by freedom and democratic thinking. Under the influence of these two forces, the United States has formed a national governance structure with a limited government and political party core. But after the industrial revolution, people who adhered to the liberal tradition suffered a crisis. The weapons of freedom and democracy could no longer help them overcome the same problems as in the past. However, people at that time also fully realized the tremendous achievements of science and technology in the physical world. To the progress of the times, scientific analysis of ideas and industrialization of technological progress through further integration of two trends of thought, people received technical rationality and professionalism two tools. 
Therefore, in the face of progress and brings a complex social and political issues, "Progressives who naturally wanted to apply to the social and political world." Politics and administration dichotomy in this context will be developed.

\section{The Theoretical Courses of Political and Administrative Dichotomy}

Theory of politics and administration dichotomy has experienced one hundred and thirty years of development, during the numerous political thinkers do this out of a theoretical contribution. It is generally believed that Wilson, the father of American public administration, first elaborated on this concept in his article "The Study of Administration". Later, Goodnow made a systematic and detailed discussion of the political and administrative dichotomy to form a theory. But as far as the truth of its origin is concerned, many scholars have pointed out that Wilson is not the earliest proponent of this term. In Europe, where administrative research is more perfect, scholars have long thought about the relationship between politics and administration. Here, we are not eager to start from $\mathrm{Eu}-$ rope, through the theoretical context of several political thinkers to sort out the trajectory of political and administrative dichotomy in the theoretical development, and make a rough description of this theory.

\subsection{Two Points of Politics and Administration in Europe}

Wilson clearly mentioned in the article "Administrative Research" that administrative management is a foreign science developed by professors in Germany and France, especially in Germany, where administrative research has almost reached perfection [5]. To this end, it is necessary to examine the stage of administrative research in Germany. The study of administrative management developed in Germany was not unrelated to the German autocratic rulers at the time. They "have absolute power and are very open-minded", trying to improve public welfare and improve administrative efficiency by improving state machines, thus mitigating domestic contradictions and conflicts. Therefore, administrative management research has a fully developed environment. As far as the study of political and administrative relations is concerned, two thinkers should mention it. One is Bluntschli. He believes that there is a clear distinction between administration and politics and law. This view is directly cited in Wilson's article "Administrative Research". The other is Stein. In his view, the state is a personality subject under the conditions of a specific social order. "It has two opposites of will and activity in the psychological sense, which is embodied in the relationship between constitutionalism and administration." Among them, "constitutionalism is the organist will of the main body, and the administration is the activity of the subject based on the will". The function of constitutional government is to limit and order administrative activities, but constitutionalism does not include administration, just as the will itself is not behavior or activity.

Some scholars said the 1937 American Public Administration literature vir- 
tually all the important concepts appear as early as before the 1859 French literature. French scholars of politics and administration dichotomy of concern are earlier. In 1812, Charles Jean Boonen proposed Administrative research should be distinguished from national and government research, because administration involves the details of policy implementation. 1845 Aleandre Vivien announced that the role of politics is to guide the direction of national ethics, while the administration is responsible for the provision of public services. French scholars' research on the dichotomy is aimed at determining where politics and administration should strike a balance, that is, preventing the arbitrariness of administrative power and ensuring the efficiency of administration. Thus, we can find a sense of European scholars that have different functions between the political and administrative, and the relationship between the two has been divided to some extent. Therefore, some scholars say its modern political and administrative dichotomy predecessor.

\subsection{Wilson's Point of View}

It is generally believed that Wilson's political and administrative dichotomy makes administrative science separate from political science as an independent science. The article "Administrative Research" is also seen as a sign of the awakening of public administration. One thing can be confirmed is that Wilson proposed the dichotomy to solve the many drawbacks brought by the party's fattening system, such as "the city government dirty atmosphere behind the scenes of the state administration, as well as common in Washington disorganized government agencies, overstaffing and corruption." In Wilson's view, the political chaos at that time stemmed from the fact that politics and administration were not divided, and the bureaucracy that relied on loyalty to the position took control of the political situation, which led to corruption. Therefore, he repeatedly emphasized in his article that the administrative distinction is different from the nature of politics in order to highlight the independent status of the administration. He wrote: "The field of administrative management is a transactional field, which is far from the chaos and conflict in the political field." administrative management being in politics do specific political issues outside the scope of the problem is not the administration, although the administrative task is to be determined. "By the political; and quoted Bloom red in the view of both the do the following distinction: "politics is a range of special events politician, is the technical and administrative management. things the staff. "to "Politics is a special activity of politicians, and administrative management is a matter of technical staff." If there is no administrative policy will help accomplish nothing, but the administration is not therefore politics". But Wilson did not completely separate politics from administration. He still emphasized the close connection between the two: "Administration is an integral part of political life. The only way to work with corporate offices at this point is social life. Part of it and the machine is a part of the manufacturing is the same. But the administrative man- 
agement is at the same time greatly higher than the monotonous content of pure technical details, the fact is based on its higher principles, it and political wisdom spawned enduring principles and political progress has eternal truths is directly associated with." Throughout the whole article, it should be said that the focus of Wilson's introduction of the dichotomy is to free the administration from political interference and to highlight the independent status of the administration, but his focus is not on the dichotomy itself. Later, Goodnow dichotomy of a more systematic theoretical exposition.

\subsection{Goodnow's Point of View}

Goodnow's "Politics and Administration" published in 1900 is called the first monograph of American administration, and Wilson's "Administration Research" is also called the pioneering work of American administration. Goodnow's political thoughts are similar to Stein. They are all influenced by social organicism and believe that "state" is a will. Therefore, in the first chapter of the book, Goodnow proposed two functions of the government: the expression of the will of the state and the execution of the will of the state. "Politics" and "administration" are words that Goodnow chose to express these two functions. "There are two main or basic government functions in all government systems, namely the expression of the will of the state and the executive function of the will of the state. There are also separate organs in every country, each with separate authority exercised by most of their time with one of the two functions is that these two functions are: politics and administration." Here politics and administration presented the development of the different characteristics is the logical premise Goodnow half, but in his view is theoretically possible to distinguish between the two, but in practice, the idea of "the separation of political and administrative functions is impossible". Therefore, he stressed that the political and administrative coordination of the two functions, namely to the administrative and political control in the case of the national will to ensure freedom of expression, but in order to ensure the efficiency of the administration, such control must be limited. "The exact limits of necessary control to be achieved by" In order to determine this, Goodnow further implementation of the will of the state is divided into "semi-scientific, quasi-judicial, part of the work and staff" and "policy The problem has a decisive part of the effect". The former is a method and technology that represents the specific implementation of the will of the state. This part of the administration should not be influenced by politics to ensure the efficiency of administration; while the latter must be properly controlled by politics to ensure that policy issues are determined by the institutions that represent the people.

Thus, we can sum up a few points Goodnow on politics and administration dichotomy of: 1) From the government's functional point of view, then, there are two functions of political and administrative. Politics is the expression of the will of the state, and administration is the execution of the will of the state; 2) The 
two functions of politics and administration are always intertwined and intertwined, and which institution is entrusted to each institution is not completely reasonable; 3) The value orientation of politics lies in democracy, and the value orientation of administration lies in efficiency; 4) politics and administration must be divided and coordinated. Politics must exercise necessary control over administration to ensure democracy. Certain parts of the administration should be free from political interference to ensure efficiency.

The theory of political and administrative dichotomy arises from the founding of public administration. Wilson was concerned about the excessive interference of political parties on administrative affairs and the corruption that spread throughout the government. Therefore, on the basis of inheriting the German administrative management thought, he proposed a paradigm of political and administrative dichotomy, in order to separate the administration from the political field. His interpretation of the dichotomy is that politics is a value-selective activity for politicians to formulate policies based on vote of voters; administration should be a specialized, professional tool for transforming specific policies. Like Wilson, Goodnow's starting point is to eliminate the ills of the party's fattening system. The difference is that Wilson's article is shorter and focuses on establishing an independent administration. Goodnow understands that politics and administration are two different functions of government, but both politics and administration can be distinguished in theory, but in practice politics must be coordinated with the administration. This is a further discussion of Goodnow's dichotomy. He makes people realize the importance of administration as a kind of government function, which causes more attention to the administrative system and its operating rules, and accelerates the separation of administrative from politics. Wilson introduced through the development and Goodnow, political and administrative dichotomy and gradually form a more complete theory. In the early establishment of public administration scholars to be regarded as a model, but in the later 1930s, it has been more and more challenges.

\section{The Controversy: Criticism from Waldo}

Since the birth of the political and administrative dichotomy, the debate surrounding it has not stopped. Many viewpoints collide and merge with each other to wipe out countless thought sparks. Until today, this issue continues to attract people to explore and argue. Among the many criticisms, Waldo is known as the representative of the "heresy" of the 20th century administrative science [6].

Waldo is one of the most famous public administration scholars of the last century. After earning a Bachelor of Arts degree from Nebraska Normal University, he entered the University of Nebraska for a Masters in Political Science. After receiving his master's degree, he went to Yale University to continue his Ph.D. Referring to the criticism of politics and administration, everyone naturally thinks of the book "Administrative Country", which was briefly come from 
his doctoral thesis "Theoretical Aspects of Literature of Public Administration". At that time, the mainstream view of the public administration academics was that public administration was a value-neutral, transcendental social science dedicated to the efficiency of government, but Waldo considered public administration to be based on political philosophy. In the book, he enthusiastically embraces the value of democracy and opposes efficiency as the core concept of administrative research. Therefore, the political and administrative dichotomy that seeks to maintain the value of neutrality in administrative science has become a major obstacle to the development of democratic administrative theory.

However, at that time, politics and administration dichotomy has received a lot of criticism, Simon, Dahl, Frederickson and others have expressed dissatisfaction with the dichotomy. They oppose the complete separation of politics and administration. So in the book "Administrative State", Waldo also sorted out the dichotomy of "going different ways" and the relationship between politics and administration is summarized as follows: "In the government process, there are only two or two functions, namely, decision-making and execution, politics and administration; administration is the field of specialized skills, and politics can and should be on excluded from this area." In Waldo's view, such a dichotomy is quite simple and rude. It is untenable, both at the factual level and at the level of guiding government behavior. "As a description of the facts, it is not appropriate because the governance process is a 'seamless network of discretion and action.' As a plan for reform, it is not appropriate because it has and It attempts to replace the three-point scheme with the same flaw: it has its own differences, dissent and opposition to it.

However, beyond these appearances, Waldo's focus is on the democratic value of public administration. He believes that although traditional administration firmly insists on the value-neutral "political and administrative dichotomy", when we go through the administrative works, we find that public administration scholars, like any political philosopher, have a "vision of a beautiful society" and tried to achieve this society. The form of government that these strategies ultimately point to is nothing more than democracy. In this regard, Waldo said: "In essence, they see democracy as an effort towards the rationality they seek. Formally, they often see democracy as external or at least attached to their field of study. This area is administrative". In other words, the essence of traditional administration is to include value, not based on the principle of value neutrality. So no matter how public administration scholars and then claim that their research is value-free, public administration inevitably become a political theory. It is only the "administration" that they advocated from politics that is not about elections, political parties, interest groups or regional politics, but "politics that pursues order, efficiency, economy, management, predictability and stability" [6]. Waldo's criticism of the political and administrative dichotomy fundamentally reflects his concerns about the status of public administration as a subject. He repeatedly emphasized the normative nature of public administration and 
the democratic mission and the essence of a political theory, criticizing the anti-democratic tradition of traditional public administration, trying to reverse the management tendency of public administration at that time and make up the foundation of its science. Waldo's theory has brought a huge impact on traditional administration, and the history of public administration has also ushered in the new public administration period. Waldo specification proposed by the study paths of Public Administration later to be called as a "Waldo path", and attracted a group of his followers.

\section{The Reality of China's Public Administration}

In addition to Waldo, many new public administration scholars, new public management scholars of politics and administration dichotomy make the criticism, and it is described as naive, illusory, erroneous unfounded. But these criticisms are undoubtedly too harsh. There is always a gap between theory and reality, because in the face of theoretical advocates, thinking is always carried out in "limited facts and clear goals". Therefore, in the early days of the founding of the United States, the founding fathers carefully designed a three-powered government system to protect the happiness of freedom. In the era of Wilson, the story has a new development. In order to resolve the contradiction between democracy and efficiency, he advocates dividing the government into two parts, political and administrative, and giving certain government agencies policy-making functions, while giving other government agencies the function of policy enforcement. This theory is also a product of the times and needs. However, administrative actions in the real world inevitably involve policy-making functions, which makes the political and administrative dichotomy seem illusory and questionable. But if we look at the US government, especially the reforms of local government, will obviously be aware of the signs of the government and the administration dichotomy, such as urban management model policy mix appeared in the American city manager system, the administrative mix and the policy of equal [7]. Therefore, the existence of the theory of political and administrative dichotomy may not be to help us reveal the truth of the real world, but to let us see the technical potential of the administration. Through the political and administrative dichotomy to achieve the structural separation of the two, we pay more attention to the administrative system and its objective operating rules, thus developing a set of effective management models and management methods. In this way, we will not be at a loss when the government functions become increasingly complicated and difficult.

Many people have compared the problems faced by the American Progressive Age with the challenges encountered in China today, and found many similarities, and suggested that we need corresponding reference, for example, the crisis of social transformation and the crisis of government governance. The social transformation in the American progressive era is a typical economic and social transformation due to industrialization and modernization. In terms of econo- 
my, industrialization and monopoly are the social aspects of the economic transformation of the United States in the advanced era. Urbanization is the expression of social transformation in the progressive era. The government governance crisis that emerged in the American progressive era lies in the economic and social structural changes and the rupture of the traditional governance model of the limited government. The government's institutional function in the original governance framework cannot function. China, which is in social transformation, is also experiencing a crisis of government governance. The original life structure system has been broken, and the new life structure system has not yet been established. The original living mechanism is difficult to continue, and the new operational order needs to be generated. A process, the change of economic and social structure challenges political structure and government governance ability. Compound, non-normative, uncertain and weakly protective are the main features of current social transformation in China. Although the government governance crisis experienced by China and the United States is very similar in content and reason, due to differences in political culture and political system, the two countries are completely different in the transformation of government governance. After the United States entered the industrialized society in 1980, the government strengthened its control over the economy and society. The government changed from a "negative" to a "positive" governance model, and the government's authority expanded. China takes the year as the demarcation point, and the governance model changes from "all-powerfulness" to "democracy and rule of law". Contrary to the United States' expansion of power, the focus of China's government governance transformation lies in the control of public power and the right to the people.

The political and administrative divisions provide a solution to the reform of the American political system at the time, but it is a theory developed in the context of the United States, adapted to the needs of a democratic country, and rooted in the political soil of the American multiparty system. The rotation of the ruling party made the government's independent administration possible. But in China's one-party political leadership of multi-party cooperation system, all attempts to try to separate politics and administration must not open around a problem, how to adhere to the party's leadership after the separation. Because the political and administrative dichotomy reflects a structural separation in the system design, the main manifestation is that the political parties representing the people are active in the legislature, while the administrative officials handle the special affairs of the government in the administrative organs in a politically neutral manner. This structural separation in China adheres to the principle of the highest political leadership of the party under almost no living space. Moreover, in China, which lacks the separation of powers and checks and balances traditions, the executive branch is the only one, and the legislature and the judiciary are relatively weak. Executive after obtaining authorization legislature, in fact, assumed responsibility for most of the policy-making, at this level, policy-making and policy implementation activities are also isolated and not suited 
to China's realities of public administration. In the final analysis, China lacks the political foundation and realistic basis for achieving political and administrative dichotomy. Therefore, in the Chinese context, China's administrative management still has to follow the path of political and administrative integration.

Although the political and administrative dichotomy cannot be the dominant paradigm of public administration in China, its high concern for government publicity and its active advocacy of values such as democracy, science and responsiveness have produced important and sustained impact on theories and practices of public administration. Understanding this point is very beneficial to the establishment of the value objectives of China's administrative reform and the choice of government behavior.

\section{Conflicts of Interest}

The author declares no conflicts of interest regarding the publication of this paper.

\section{References}

[1] Demir, T. and Nyhan, R.C. (2010) The Politics-Administration Dichotomy: An Empirical Search for Correspondence between Theory and Practice. Public Administration Review, 68, 81-96. https://doi.org/10.1111/j.1540-6210.2007.00839.x

[2] Doyle, M.W. (1986) Liberalism and World Politics. American Political Science Review, 80, 1151-1169.

[3] Wilson, W. (2009) The Study of Administration. Political Science Quarterly, 56, 481-506. https://doi.org/10.2307/2143644

[4] Rosenbloom, D. (2010) The Politics-Administration Dichotomy in U.S. Historical Context. Public Administration Review, 68, 57-60. https://doi.org/10.1111/j.1540-6210.2007.00836.x

[5] Martin, D.W. (1987) Déjà vu: French Antecedents of American Public Administration. Public Administration Review, 47, 297-303. https://doi.org/10.2307/975309

[6] Overeem, P. (2008) Beyond Heterodoxy: Dwight Waldo and the Politics Administration Dichotomy. Public Administration Review, 68, 36-45. https://doi.org/10.1111/j.1540-6210.2007.00833.x

[7] Svara, J.H. (1998) The Politics-Administration Dichotomy Model as Aberration. Public Administration Review, 58, 51-58. https://doi.org/10.2307/976889 